\title{
Strengthening graduate employee commitment through internal marketing in the South African retail banking industry
}

\author{
M. Roberts-Lombard ${ }^{* 1}$ and L Reynolds-de Bruin \\ University of Johannesburg, Auckland Park Campus, PO Box 524, Auckland Park, 2006, South Africa \\ *To whom all correspondence should be addressed \\ mornayrl@uj.ac.za
}

\begin{abstract}
A strong internal marketing strategy can be critical to achieving and sustaining a competitive advantage as well as driving organisational change and enhanced organisational performance. This study sought to determine the influence of internal marketing mix elements on the satisfaction levels of recently employed graduates (GradDPs) within the retail banking industry in South Africa. The study also identified links between the satisfaction of GradDPs and their affective commitment in this context. A census approach to generating data was applied in the study by using a person-administered and an electronic survey method. Regression analysis was used to test the relationships proposed in the study. The results indicated that internal marketing significantly influences GradDP employee satisfaction within retail banks in South Africa and that a positive relationship exists between GradDP employee satisfaction and their affective commitment. The study results allowed for recommendations that retail banks provide training and support programmes to assist managers in developing a more participative style of leading. Such programmes would assist leaders in consulting employees more often and ensuring that they have sufficient autonomy when executing their work. It would also help leaders to create a safer GradDP employee environment that fosters openness, risk-taking and idea generation.
\end{abstract}

\section{Introduction}

The growth of the service sector worldwide has led to services being considered as one of the most important sectors in the world (Global Services Forum, 2013; CIA, 2012; Global Entrepreneurship Monitor, 2011; Mishra, 2010). The contribution of the South African service sector to GDP was $68.4 \%$ in 2015, and the financial services sector in South Africa had already overtaken the manufacturing sector as the largest contributor to GDP (IndexMundi, 2015 citing the CIA; National Treasury, 2011). Given the homogeneity within the retail banking industry, there is very little differentiating the banks, and imitation of any innovation is inevitable. For this reason a market-driven strategy that enables retail banks to deliver superior quality is essential as service quality is the only real differentiator and key to building a competitive advantage (Culiberg \& Rojsek, 2010:152, Kotler et al., 2010). Since it is the bank's employees who create the service experience, the employee as the internal customer becomes the organisation's most valuable asset. For this reason, retail banks in South Africa have increasingly focused on recruiting at the graduate level, leading to the establishment of graduate development programmes (GradDPs) (Leonard \& Murphy, 2013). These banking GradDPs are specifically designed to help graduates succeed in complex environments and to build the talent pipeline by providing an in-depth training programme (FNB,
2011; ABSA, 2011). However, one of the biggest challenges faced by banks is the satisfaction and retention of their GradDP employees. Banks generally experience high attrition rates amongst this group of employees mainly due to job dissatisfaction which affects service quality provided to external customers, and increases the organisation's costs (McDermott, Mangan \& O'Connor, 2006). Organisations wanting to succeed in today's global economy will need to focus on ways to improve employee satisfaction. One such approach is through the use of internal marketing. An internal marketing programme aimed at employees and the use of the extended services internal marketing mix (internal product, internal price, internal distribution, internal promotion, internal people, internal process and internal physical evidence) could enhance employee satisfaction which in turn could enhance employee levels of affective commitment resulting in higher retention rates (Illiopoulos \& Priporas, 2011; Calisir, Gumussoy \& Iskin, 2011).

The study makes a contribution to the academic literature by indicating that previously identified elements of the extended Internal Marketing mix do have an influence on employee satisfaction and its outcome (employee commitment) in a South African context. A model was proposed and validated that indicate the relationships between identified Internal Marketing mix elements, employee satisfaction and employee commitment amongst GDP employees within the

\footnotetext{
${ }^{1}$ Acknowledgement: This work is based on the Masters degree dissertation of Leigh Reynolds-de Bruin entitled 'The influence of internal marketing on internal customer satisfaction within retail banking' submitted to the University of Johannesburg. The co-author of this article was the supervisor of the dissertation.

Disclaimer: Any opinion, finding and conclusion or recommendations expressed in this material is that of the authors and the University of Johannesburg does not accept any liability in this regard.
} 
South African retail banking environment. From a managerial perspective, the study contributes in potentially assisting the South African retail banking industry in understanding how identified elements of the extended Internal Marketing mix can secure employee satisfaction, eventually leading to positive GDP employee commitment.

This article provides a theoretical review of the different elements of the internal marketing mix, and the linkage between internal marketing, employee satisfaction and employee commitment. The problem investigated in the study that informed this article is specified, followed by a discussion on the research objectives, hypotheses and methodology employed. Thereafter, the empirical results are discussed, followed by a discussion of the theoretical and practical contribution of the study and the implications the results of the study might hold for the management of retail banking in South Africa.

\section{Theoretical framework}

Considering the homogeneousness nature of the South African retail banking industry, limited scope for differentiation is available and the duplication of any innovation is unavoidable. Therefore, South African banks need to adopt a market-driven strategy that will allow them to deliver higher levels of service quality as a form of differentiation in securing a competitive advantage (Culiberg \& Rojsek, 2010:152, Kotler et al., 2010:19). Service quality is perceived as a critical element of business marketing and financial performance and has been acknowledged as a strategic factor for organisations functioning in service sectors. Banks hold the view that customers will be loyal if they are provided with more value than from competitors and should therefore emphasise the improvement of service quality as a key competitive strategy (Ouyang, 2010:77).

Internal marketing as an 'employee-focused' strategy aims at marketing the organisation inwardly to the employees through their jobs as internal products. In this way employees become more customer-orientated and strive for higher levels of service excellence (Akroush, Abu-ElSamen, Samawi \& Odetallah, 2013). It is regarded as an important mechanism needed to balance the relationship between employee satisfaction and external customer satisfaction. The reason being that satisfied external customers depends on satisfied employees who are encouraged to constantly deliver high standards of service quality (Hume and Hume, 2015). To create this kind of balance, an internal marketing mix is required. The internal marketing mix elements, namely internal product, internal price, internal promotion, internal distribution, internal people, internal process and internal physical evidence (Burin, 2011) were used in this study as each element addresses the identified employee satisfaction predictors adopted. These satisfaction predictors are reward and recognition (including salary and benefits), career advancement (promotional opportunities), work environment (including personal safety), leadership, relationship with supervisors/managers, relationship with co-workers, stress and pressure, role clarity and fit, empowerment, training and development, feedback, decentralised decision-making, sharing of knowledge and information, and organisational culture (Ahmad, Wasay \& Malik, 2012; Halepota \& Shah, 2011; Turkyilmaz, Akman, Ozkan \& Pastuszak, 2011). The theories grounding the study, the different internal marketing mix elements and their link to employee satisfaction are discussed below.

\section{Theories grounding the study}

The study is based on the philosophies of the Relationship Marketing theory and Social Exchange theory in relation to the different constructs that are investigated and the suggested relationships amongst the different constructs. Relationship marketing is described as marketing focused activities that is focussed on the establishment, development and maintenance of positive relational exchanges (Morgan and Hunt, 1994). Bojei and Abu (2014) concur and argue that relationship marketing is acknowledged as an organisational strategy that is based on the principle of long-term relationship development and retention through augmented loyalty, trust, commitment and satisfaction. The focus of relationship marketing has changed since the 1990's from a customer development perspective to also include a focus on employee development and retention (Gummesson, 2014). Ruizalbaa, Bermúdez-Gonzáleza, Rodríguez-Molinab and Blancaaa (2014) state that Internal Marketing is becoming an important organisational strategy since the performance and attitude of employees are critical elements in the service delivery process of an organisation. Considering this, organisations need to become more focused on the application of their human resource policies and procedures to manage personnel as internal customers that needs to be developed and motivated to serve customers more effectively (Huang and Rundle-Thiele, 2015). Therefore, an Internal Marketing strategy focus on employees as the internal customers of the organisation, and through positive employee performance acknowledgement and satisfaction the organisation can secure external operational success (Imran, Arif, Cheema and Azeem, 2014; Zaman, Javaid, Arshad and Bibi, 2012).

In terms of social exchange theory, Tanskanen (2015) postulate that the theory is founded on the principle of volunteer exchange of value between parties (e.g. people or organisations) who aim to capitalise on gains within a social system. This implies that for the parties involved in the exchange (e.g. people and/or organisations) something of value has to be provided and something of value has to be returned. Therefore, the exchange secures outcomes for all parties involved that is founded on mutually rewarding transactions (Malmström and Johansson, 2016). Considering this, Lioukas and Reuer (2015) argue that the theory of social exchange is founded on the reciprocity belief. This belief is the departing argument for social exchange theory from an internal marketing perspective seeing that both the organisation and the employee has a responsibility to recompense for benefits received. Therefore, if the social exchange of value towards employees are characterised by training, development, empowerment and engagement in 
decision making, the reciprocal expectation will be enhanced service delivery to external customers to strengthen customer service experience, commitment and loyalty (Atan, Raghavan, Hasnaa and Mahmood, 2015; Jodie Conduit, Matanda and Mavondo, 2014; Ferdous, Herington and Merrilees, 2013; Jun and Cai, 2010).

Considering the theories discussed above, the study departs from the theoretical foundation of these theories to develop the hypotheses of the relationships between the constructs of the study, in respect of the South African retail banking industry, to establish the influence of the internal marketing mix on employee satisfaction from a GradDP employees' perspective in order to potentially strengthen their satisfaction with graduate development programmes. In turn, the relationship between employee satisfaction and affective commitment was also investigated. As far as the authors could determine, no previous study in the context of the South African banking industry has applied the Relationship Marketing and Social Exchange Theory to understand the factors that influence employee satisfaction, thereby guiding future affective commitment.

\section{Internal marketing mix}

\section{Internal product}

Yang (2012) refers to internal product as the employee's job accompanied with the basic operational skills of the training programme. A successful service organisation must first sell the job to employees before it can sell its services to external customers. Yang (2012), Grayson and Sanchez-Hernandez (2010) are of the opinion that elements such as training and development, empowerment, career advancement, role fit and clarity constitute the components of internal product. Therefore, it is imperative that employees relate to all aspects of their job in a positive manner and are satisfied users of the internal product thereby securing a greater external customer orientation and customer satisfaction experience (Hume and Hume, 2015). Atan, Raghavan, Hasnaa and Mahmood (2015) concur and state that to enhance employee satisfaction with the internal product, training needs to empower employees with the required skills that will enhance their overall performance ability.

\section{Internal price}

Zeithaml, Bitner and Gremler (2012) explain that internal price refers to the price that employees pay to work for the organisation, in other words the sacrifices that they make. Internal price will thus include opportunity costs, psychological costs and emotional labour costs. In support of this explanation, Karatepe (2011) as well as Bakker and Demerouti (2007) state that the employee bears many costs that are not monetary-based, but more intrinsic in nature. These intrinsic costs relate to the price employees pay to work for the organisation; in other words, the sacrifices they make. Huang (2010) suggests that work-family balance is a major contributor to internal price from a stress and burnout perspective and needs to be taken into consideration. If work- family life is not balanced in an effective manner, employees are likely to be dissatisfied and seek employment elsewhere (Schneider, 2013).

\section{Internal promotion}

Internal promotion, which comprises promotional tactics such as internal advertising, personal selling (face-to-face communications), internal sales promotion and social media applied to the internal market of the organisation, refers to the manner in which organisations share information with employees with the outcome to motivate them to support the objectives of the organisation (Gummesson, Lusch \& Vargo, 2010; Javadein, Rayej, Estiri \& Ghorbani, 2010). Chen and Huang (2007) believe that the main purpose of internal promotion is to create knowledge and skills within the organisation so that employees understand exactly what is expected of them to perform their jobs well. Well-informed employees who understand the organisation's vision, objectives and brand and how these elements relate to their jobs become the organisation's best brand ambassadors, also reflecting greater levels of employee satisfaction. Narteh and Odoom (2015) concur and state that internal promotion encompass the communication of human resources management values that guides personnel in the delivery of enhanced services levels to external customers.

\section{Internal distribution}

The objective of internal distribution is to create an internal environment that supports the accomplishment of specific goals and objectives in order to achieve higher levels of satisfaction. This objective may be achieved by examining where changes are required, what resources are required and employee empowerment through cultural and structural adjustments to achieve higher levels of satisfaction resulting in enhanced service delivery and a positive brand image (Baldauf, Cravens, Diamantopoulos \& Zeugner-Roth, 2009). Burin, Roberts-Lombard and Klopper (2015) concur by stating that "if there is a lack of synergy amongst different departments within the staffing agency, then the service offered to the client will not be as reliable and responsive as it could be".

\section{Internal people}

Peters and Mazdarani (2008) describe 'internal people' as the people involved in delivering the internal product (job) and those receiving the internal product (job) which may influence the internal customer's (employee's) perception. From an internal marketing perspective, the employee is the internal customer whose perception of the service encounter is affected by internal suppliers and other employees in the environment (Guzman, Rodriguez \& Manautou, 2013). Ozuem, Limb and Lancaster (2016) concur and state that through skills development training, internal service delivery can be enhanced thereby securing a stronger focus on external service delivery. They further argue that through professional training, personnel-specific skills are not easily duplicated and can produce a competitive advantage. Turkyilmaz et al. 
(2011) suggest that from an employee satisfaction perspective, the relationships with leaders, supervisors/direct managers and co-workers have an impact on the employee as employees' behaviour depends on their interaction with others in the internal environment.

\section{Internal process}

The process of the internal marketing mix relates to how the internal customer receives the internal product and includes work processes. If the employee knows what to do and how to do it, competency and improved satisfaction are enhanced (Uzzi, 2010). Kaur and Sharma (2015) concur and state that the ability of the organisation to satisfy external customer needs will depend on both the commitment level of employees towards the organisation and the internal level of satisfaction experienced by employees. Sahi, Lonial, Gupta and Seli (2013) and Che Ha et al. (2007) argue that the internal sources of the organisation need to be coordinated in order to achieve organisational commitment securing superior value to external customers. That is why securing the organisational commitment of employees will ensure improved organisational loyalty, enhanced job performance and illustrate high levels of organisational citizenship behaviour (Woo Joung, Goh, Huffman, Yuan and Surles (2015). No area of operation can function in isolation, and employees across functional areas need to work together in order to deliver value for customers. Therefore, from an internal perspective, internal processes that are streamlined and effective could lead to better service delivery and organisations that succeed in the delivery of service excellence and faster turnaround times will keep more customers satisfied (Ndubisi and Ndubisi, 2013; Gebre, Hallman, Minukas \& O’Brien, 2012).

\section{Internal physical evidence}

Holder and Berndt (2011) describe the physical environment or servicescape as the physical facility or actual working environment where the service is provided. Organisations rely heavily on physical evidence to create perceptions of service quality for customers (Lenke, Suar \& Mohapatra, 2010). The physical environment also helps to create positive word-of-mouth as customers recommend pleasing environments. Furthermore, physical evidence enhances employee satisfaction, as well-designed areas improve employee satisfaction, create a positive work ethic and reduce employee turnover (Newsham et al., 2009; Lee, 2006: 343).

Against the background provided above, the underlying objective of internal marketing is the development of a marketing programme which is directed at the internal market of the organisation (i.e. employees). The overall aim of such an internal marketing programme should be to consider and meet employee needs in order to bring about higher levels of employee satisfaction (Ozuem, Limb and Lancaster, 2016 and Ruizalbaa, Bermúdez-Gonzáleza, Rodríguez-Molinab, Blancaaa, 2014). Through such an approach, the organisation is able to secure the creation of internal customer value, thereby enhancing external customer experience and satisfaction (Fang, Chang, Ou and Chou (2014). Considering this principle, the next section highlights the link between internal marketing and employee satisfaction.

\section{Internal marketing and employee satisfaction}

Through an internal marketing programme the predictors of employee satisfaction can be addressed. This means that if successfully implemented, these internal marketing activities would result in the following outcomes: better job design would promote a better role fit, and role clarity (internal product) would ensure that jobs match the individual's abilities and competencies (Ahmad et al., 2012; Halepota \& Shah, 2011; Turkyilmaz et al., 2011). Mac and Shirley (2015) concur by arguing that the understanding of internal marketing needs to be "a planned effort using a marketing like approach to overcome organisational resistance to change and to align, motivate and inter functionally co-ordinate and integrate employees towards the effective implementation of corporate and functional strategies in order to deliver customer satisfaction through a process of creating motivated and customer-orientated employees"

Grayson and Sanchez-Hernandez (2010) state that the integration and coordination (internal distribution) across functions, as well as more participative leadership styles (internal people), would reduce service failures because operations and functions would be better coordinated and aligned with customers' needs and behaviours during the encounter. As a result, conflicts with customers as well as friction between back office and front office staff would reduce, improving relations with co-workers (internal people), which would result in higher levels of employee satisfaction. This would help reduce stress and emotional labour costs (internal price). Communication (internal promotion) would be more effective, and performance feedback (internal physical evidence) as well as the timely exchange of information would improve employees' perception of communication quality which would also lead to increased satisfaction (Grayson \& Sanchez-Hernandez, 2010). Yang, Huang and Wei (2015) emphasise the importance of internal marketing in securing employee wellbeing. They argue that employees want to feel part of the organisation through an emotional attachment to its corporate vision (internal promotion), and that employee recognition can secure higher levels of commitment, productivity, job satisfaction and employee retention. Imran, Arif, Cheema and Azeem (2014) also contend that employee benefits (e.g. salary, fringe benefits) (internal product) as well as the physical environment in which the employee performs his/her duties (internal physical evidence) has a direct influence on employee performance ability and overall employee satisfaction.

Turkyilmaz et al. (2011) contend that if employees are unhappy in their internal environment, they are likely to feel disengaged, less empowered and less appreciated, and they would be driven to withdraw from the organisation and seek employment elsewhere. Therefore it should be noted that when management obtain knowledge on the expectations of employees through an internal marketing analysis and tasks 
are designed around such expectations, employees will become more positive towards their work environment. Such an improvement in employee attitude will increase employee satisfaction, resulting in increased external customer satisfaction (Fang, Chang, Ou and Chou, 2014).

Based upon these findings, the following hypotheses can be formulated for the study:

H1: There is a significant positive relationship between the internal product and GDP employee satisfaction

H2: There is a significant positive relationship between the internal price and GDP employee satisfaction

H3: There is a significant positive relationship between the internal promotion and GDP employee satisfaction

H4: There is a significant positive relationship between the internal distribution and GDP employee satisfaction

H5: There is a significant positive relationship between the internal people and GDP employee satisfaction

H6: There is a significant positive relationship between the internal process and GDP employee satisfaction

H7: There is a significant positive relationship between the internal physical evidence and GDP employee satisfaction

The next section explores the link between employee satisfaction and affective commitment.

\section{The linkage between employee satisfaction and affective commitment}

Ruizalba, Bermúdez-Gonzáleza and Rodríguez-Molinab, Blanca (2014) state that the ability of organisations to develop an internal environment that is supportive of the development of relationships between management and employees and employees themselves, will result in higher levels of satisfaction among employees which will have a positive influence on job commitment. Employee satisfaction is regarded as a prerequisite for commitment and loyalty, meaning that commitment and loyalty develop from satisfaction and mediate the effects of satisfaction on turnover variables. Therefore, when employee satisfaction is high, employee commitment and loyalty will also be higher (Gibbs \& Ashill, 2013). Kanyurhi and Akonkwa (2016) concur and also argue that there is a direct link between employee commitment to the organisation and the level of satisfaction experienced by the employee towards its internal, working environment. Affective commitment is synonymous with loyalty and has been identified as the strongest predictor of employee intention to remain with organisations (Calisir et al., 2011). Such commitment has been described as the employee's state of emotional commitment to the organisation and is influenced by a factor such as organisational support (Awwad \& Agti, 2011). The study on which this article is based focused on affective commitment, since it has been demonstrated as having a strong positive relationship with job satisfaction and organisational outcomes such as turnover intentions and financial performance (Dimitriades \& Papalexandris, 2011). Yang, Lee and Cheng (2016) concur and state that management that are effectively engaged with employees in the setting of their work goals, the development of their skills training based on their needs and expectations to perform their tasks better will strengthen the affective commitment of employees and make them more loyal towards the organisation. Appelbaum, Makarenko, Saluja, Meleshko and Kulbashian (2013) argue that affective commitment is influenced by the exchange process. When an employee compares the costs and benefits of being employed by the organisation and are of the opinion that employee needs and expectations have been satisfied, the employee will experience a feeling of satisfaction. Such satisfaction engenders an affectively committed state to the organisation or work environment, resulting in higher levels of retention (Huang and Chen, 2013).

Based upon these findings, the following hypothesis can be formulated for the study:

H8: There is a significant positive relationship between GDP employee satisfaction and affective commitment

Against the background provided above, Figure 1 depicts the proposed theoretical model for this study, illustrating the different constructs of the study as well as the hypothesised relationships between these constructs.

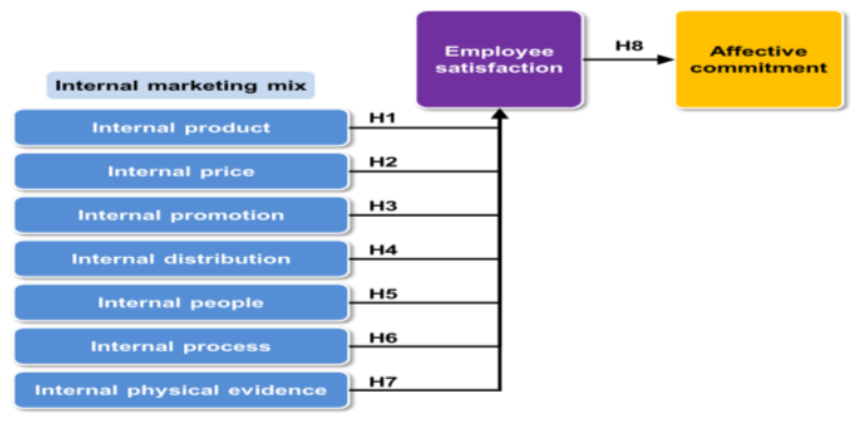

Figure 1: Proposed theoretical model

Source: Researchers own construct.

\section{Problem statement}

Previous internal marketing studies within the banking industry have focused on employees' understanding of corporate values, market orientation, employee commitment, service quality, customer satisfaction and loyalty (Sahi et al., 2013; Kameswari \& Rajyalakshmi, 2012; Aburoub, Hersh \& Aladwan, 2011; Abzari \& Ghujali, 2011; Awwad \& Agti, 2011). Peltier, Pointer and Schibrowsky (2008) conducted a number of studies exploring the link between internal marketing and satisfaction in the nursing industry. However, no studies, either locally or internationally, could be found on the influence of internal marketing as a means of achieving 
satisfaction amongst retail banking GDP employees. In addition, no studies could be found linking the elements of the internal marketing mix (internal product, internal price, internal promotion, internal distribution, internal people, internal process and internal physical evidence) to employee satisfaction. This raises the question as to whether internal marketing does in fact have a positive influence on the satisfaction levels of retail banking GDP employees in South Africa. Further to this, various studies by Appelbaum et al. (2013), Lumley, Coetzee, Tladinyane and Ferreira (2011) and Boles et al. (2007) link employee satisfaction to affective commitment. Therefore, the study sought to explore the link between employee satisfaction and affective commitment due to its influence in retaining graduate employees.

Taking the above into consideration, the key problem seems to be that the influence that the internal marketing mix elements have on employee (graduate) satisfaction within the retail banking industry in South Africa tends to be unexplored and therefore the relationship between employee satisfaction and affective commitment remains unclear.

\section{Objectives}

The primary objective of the study was to investigate the influence of the internal marketing mix on employee satisfaction from a GradDP employees' perspective in order to possibly enhance their satisfaction with graduate development programmes at retail banks in South Africa. In addition to this, the relationship between employee satisfaction and affective commitment was also explored.

The primary objective of the study was supported by the following secondary objectives, namely (1) to determine whether GDP employees are aware of the internal marketing mix elements at their bank; (2) to establish GDP employees' level of satisfaction with their bank as an employer, (3) to determine whether a significantly positive relationship exists between the different elements of the internal marketing mix and employee satisfaction, and (4) to establish whether a significantly positive relationship exists between employee satisfaction and affective commitment

\section{Research methodology}

A descriptive research design was employed in order to secure a large sample size through the use of a survey. The study aimed at generating quantitative data to provide results that could be generalised and flows from the masters degree dissertation of Leigh de Bruin-Reynolds, published at the University of Johannesburg under the title "The influence of internal marketing on internal customer satisfaction within retail banking'. A positivistic paradigm was accepted for the study since verifiable knowledge is possible in the social sciences by formulating and testing hypotheses that relate to identifiable and measurable variables (Kent, 2007). Given that the GradDP group of employees constitutes a small population and employees and that they could be contacted with ease at a low cost, it was decided that a census approach to research participation would be appropriate. All GradDP employees from the South African retail banks offering GradDP programmes were approached to participate in the study. Three of the 'Big Four' retail banks of South Africa agreed to participate in the study, making up the sampling frame. These three banks were considered as representative of the retail banking industry in South Africa as collectively they held $62.1 \%$ of the South African market share (Banking Association South Africa, 2011). All 360 GradDP employees in the sample frame were invited to participate in the questionnaire survey. A combination of both personadministered and electronic survey methods was used in accordance with the needs and requirements of each participating bank. A total of 164 usable questionnaires were eventually returned.

The questionnaire was designed relevant to the problem statement and research objectives. The opening part of the questionnaire included a demographic section with the aim of categorising the type of employee who responded and the first section of the questionnaire measured the participants' awareness of the internal marketing mix. The second section focused on the importance of the internal marketing mix to job satisfaction, the third section measured perceptions of employee satisfaction, and the fourth section elicited employees' perceptions of affective commitment. Relevant literature was employed to aid in the development of the measurement constructs and previous studies were used where applicable and possible. Data were collected for the four distinct sections using a five-point interval Likert scale, ranging from $1=$ 'strongly agree' to $5=$ 'strongly disagree'. Linear regression analysis was used to test the relationship between the internal marketing mix elements and employee satisfaction, and also to test the relationship between employee satisfaction and affective commitment. In order to determine the reliability of the measuring instrument, Cronbach alpha was calculated and an exploratory factor analysis was used to test for validity. The Statistical Consulting Department of the University of Johannesburg (STATKON) assisted in the analysis of the data.

\section{Results}

\section{Construct validity and reliability}

The Kaiser-Meyer-Olkin (KMO) statistics ranged between average $(\mathrm{KMO}=0.550)$ and large $(\mathrm{KMO}=0.882)$. The Bartlett test of sphericity had p-values all equal to zero, indicating that the values were significant $(p<0.05)$ for the factors created from the questionnaire. Most of the cumulative percentages ranged between $50 \%$ and $75 \%$ and were therefore considered to explain a sizable amount of the variance. Cronbach alpha values of .80 or higher are considered as of high reliability; those between 0.70 and 0.80 are regarded as having good reliability; values between 0.60 and 0.70 are fair and coefficients lower than .60 are questionable (Hair, Wolfinbarger, Ortinau \& Bush, 2010:708). Table 1 summarises the results of the Cronbach alpha test. 
Table 1: Results of the Cronbach alpha test

\begin{tabular}{c|l|c}
\hline \multicolumn{2}{c|}{ Construct } & $\begin{array}{c}\text { Cronbach } \\
\text { Alpha }\end{array}$ \\
\hline \multirow{4}{*}{$\begin{array}{c}\text { Internal } \\
\text { marketing } \\
\text { mix }\end{array}$} & Internal product & 0.887 \\
\cline { 2 - 3 } & Internal price & 0.789 \\
\cline { 2 - 3 } & Collaborative culture & 0.758 \\
\cline { 2 - 3 } & Organisational structure & 0.796 \\
\cline { 2 - 3 } & Internal people & 0.884 \\
\cline { 2 - 3 } & Internal process & 0.766 \\
\hline \multicolumn{2}{|c|}{ Employee satisfaction } & 0.890 \\
\hline \multicolumn{2}{|c|}{ Affective commitment } & 0.923 \\
\hline
\end{tabular}

The Cronbach alpha scores for the internal marketing mix varied between 0.766 and 0.887 . The internal promotion scale and internal physical evidence scale had been removed due to poor construct validity and as a result were not included in the reliability assessment. As can be inferred from Table 1, all the subscales reported good internal consistency reliability. Internal product $(\alpha=0.887)$ and internal people $(\alpha$ $=0.884)$ had the highest levels of reliability. Although somewhat lower than internal people and internal product, all the remaining subscales reported sufficient levels of reliability [Internal price $(\alpha=0.789)$, collaborative culture $(\alpha$ $=0.0758)$, organisational structure $(\alpha=0.796)$ and internal process $(\alpha=0.0766)]$. The Cronbach alpha score for employee satisfaction $(\alpha=0.890)$ indicated a high level of reliability, as did the Cronbach alpha score for affective commitment $(\alpha=0.923)$. Thus, considered collectively, all the measurement scales reported good levels of internal consistency reliability as measured by the Cronbach's alpha coefficient.

\section{Results}

Initially, multiple regression analysis was considered for the study as, through such analysis, the internal marketing mix scales could be applied as a group to determine the influence of the elements on employee satisfaction. Moreover, multivariate regression analyses would have allowed for determining which of the internal marketing mix elements emerged as the strongest predictor of employee satisfaction. However, during the analysis phase no single element emerged as most influential or strongest and for this reason each element was regressed individually against satisfaction in order to assess the strength of each relationship individually. Due to the reasons discussed, a simple linear regression was applied to the study to test the formulated hypotheses. Factor scores used in the regression analysis were computed based on the refined measures and not the original scales. The internal distribution subscale emerged as a twofactor solution during the Exploratory Factor Analysis (EFA) and as a result was split into two factors labelled as collaborative culture and organisational structure. For this reason the hypothesis was split into H4a ('There is a significantly positive relationship between collaborative culture and GDP employee satisfaction') and H4b ('There is a significantly positive relationship between organisational structure and GradDP employee satisfaction'). Internal promotion and internal physical evidence were excluded from the regression analysis since the items in these constructs were not perceived as fit from a validity perspective and removed based on the exploratory factor analysis. Section 1 of the discussion below focuses on the relationship between the internal marketing mix elements and employee satisfaction which will aim to measure hypotheses 1 to 7 . Section 2 focuses on the relationship between employee satisfaction and affective commitment, aiming at the measurement of hypothesis 8 .

\section{Section 1}

H1: There is a significantly positive relationship between the internal product and GDP employee satisfaction.

The results indicate a positive relationship between internal product and employee satisfaction and the results from the regression analysis support the hypothesis $(\beta=0.548, p<$ 0.05 ). The direction of the relationship was congruent with $a$ priori theorising since a moderately positive relationship was predicted between internal product and employee satisfaction. Thus, the null hypothesis can be rejected in favour of the alternative hypothesis. The adjusted $\mathrm{R}^{2}$-value of 0.289 indicates that approximately $28 \%$ of the variance in employee satisfaction is predicted by internal product. There is thus a significantly positive relationship between internal product and employee satisfaction, indicating that $\mathrm{H} 1 \mathrm{can}$ be accepted. Hume and Hume (2015) supports this view stating that employee satisfaction depends on the alignment of their job design with their internal service expectations, thereby enhancing both employee commitment and the quality of internal service delivery.

\section{H2: There is a significantly positive relationship between the internal price and GDP employee satisfaction.}

According to the results, a positive relationship between internal price and employee satisfaction was established. The $\beta$ results from the regression results support the hypothesis $(\beta$ $=0.216)$. However, the $\mathrm{p}$-value is greater than $0.05(\mathrm{p}=0.86)$ and therefore not statistically significant. Internal price is therefore not statistically significant. Considering this, Leong and Lam (2016) argue that the job satisfaction of employees will depend on their perception of their employer expectations through job task delivery and the investment that the employer is willing to make through reward systems and training and development opportunities created.

\section{H3: There is a significantly positive relationship between internal promotion and GDP employee satisfaction.}

The relationship between internal promotion and employee satisfaction could not be tested as the internal promotion 
subscale was discarded due to poor construct validity and no further testing was conducted for this construct.

\section{H4a: There is a significantly positive relationship between collaborative culture and GradDP employee satisfaction.}

From the results it was established that a positive relationship exists between collaborative culture and employee satisfaction. The results from the regression support the hypothesis $(\beta=0.338, p<0.05)$. The direction of the relationship was congruent with a priori theorising since a moderately positive relationship was found between collaborative culture and employee satisfaction. Thus, the null hypothesis can be rejected in favour of the alternative hypothesis. The adjusted $\mathrm{R}^{2}$-value of 0.114 indicates that approximately $11.4 \%$ of the variance in employee satisfaction is predicted by collaborative culture. Considering this, there is a significantly positive relationship between collaborative culture and employee satisfaction, indicating that $\mathrm{H} 4 \mathrm{a}$ can be accepted. Helm, Renk and Mishra (2016) concur with this finding by stating that employee satisfaction is guided by the employee's self perception of his or her role and function within the organisation, the ability to engage with fellow employees on task performance as well as alignment of the individual values of the employee with that of other employees and the organisation.

\section{H4b: There is a significantly positive relationship between organisational structure and GradDP employee satisfaction.}

The results from the regression supported hypothesis $4 \mathrm{~b}$ that a positive relationship was established between organisational structure and employee satisfaction $(\beta=0.431$, $p<0.05)$. The direction of the relationship was congruent with a priori theorising since a moderately positive relationship was found between organisational structure and employee satisfaction. Thus, the null hypothesis can be rejected in favour of the alternative hypothesis. The adjusted $\mathrm{R}^{2}$-value of 0.185 indicates that approximately $18.5 \%$ of the variance in employee satisfaction is predicted by organisational structure. Therefore, a significantly positive relationship exists between organisational structure and employee satisfaction, indicating that $\mathrm{H} 4 \mathrm{~b}$ can be accepted. As $\mathrm{H} 4 \mathrm{a}$ and $\mathrm{H} 4 \mathrm{~b}$ were both accepted, $\mathrm{H} 4$ can also therefore also be accepted. According to Ferdous, Herington and Merrilees (2013), the internal marketing strategy of an organisation should be supportive of management and employee engagement. An internal marketing strategy that focused less on management instruction and more on employee engagement can lead to greater employee affective outcomes, performance outcomes, and firm-employee relationships.

\section{H5: There is a significantly positive relationship between internal people and GradDP employee satisfaction.}

The results from the regression support hypothesis H5 ( $\beta=$ $0.571, \mathrm{p}<0.05)$ that a positive relationship exists between internal people and employee satisfaction $(\beta=0.571, p<$
0.05). The direction of the relationship was congruent with $a$ priori theorising since a moderately positive relationship was found between internal people and employee satisfaction. Thus, the null hypothesis can be rejected in favour of the alternative hypothesis. The adjusted $\mathrm{R}^{2}$-value of 0.326 indicates that approximately $32.6 \%$ of the variance in employee satisfaction is predicted by internal people. A significantly positive relationship therefore exists between internal people and employee satisfaction, indicating that $\mathrm{H} 5$ can be accepted. This finding is in alignment with a study by Mishra and Sihna (2014) stating that employee satisfaction is dependent on how the organisation motivates its employees. Such motivation is guided by four basic principles, the ability of the organisation to involve employees in the decision making process, the investment made in the training and development of employees, the ability to have develop an engaging and open communication culture with employees and an understanding for the foundations that drives employee motivation within the organisation.

H6: There is a significantly positive relationship between internal process and GradDP employee satisfaction.

From the results to measure hypothesis H6, a positive relationship was found between internal process and employee satisfaction, thus supporting the hypothesis $(\beta=$ $0.399, p<0.05)$. The direction of the relationship was congruent with a priori theorising since a moderately positive relationship was found between internal process and employee satisfaction. Thus, the null hypothesis can be rejected in favour of the alternative hypothesis. The adjusted $\mathrm{R}^{2}$-value of 0.159 indicates that approximately $15.9 \%$ of the variance in employee satisfaction is predicted by internal process. Considering this, a significantly positive relationship exists between internal process and employee satisfaction, indicating that H6 can be accepted. Sharma, Kong and Kingshott (2016) are in agreement with this finding stating that the principles that guides external service delivery quality should also be the foundation for internal service delivery amongst the employees of an organisation. Internal customers (employees) are engaged in a large number of service encounters on a daily basis as part of their daily responsibilities. This requires a professional, friendly and focused approach that will stimulate employee satisfaction and productive service delivery.

\section{H7: There is a significantly positive relationship between internal physical evidence and GradDP employee satisfaction.}

The relationship between internal physical evidence and employee satisfaction could not be tested as the internal physical subscale was discarded due to poor construct validity and no further testing was conducted for this construct. When entered into the regression equation individually through step-wise regression, the highest level of variance in employee satisfaction was predicted by the internal people element $\left(\beta=0.571, \mathrm{R}^{2}=0.326\right)$. The next highest level of variance in employee satisfaction was predicted by internal product $\left(\beta=0548, \mathrm{R}^{2}=0.289\right)$. This was followed by organisation structure $\left(\beta=0.431, \mathrm{R}^{2}=0.185\right)$, 
then by internal process $\left(\beta=0.399, \mathrm{R}^{2}=0.159\right)$, and finally by collaborative culture $\left(\beta=0.338, \mathrm{R}^{2}=0.114\right)$. Internal price was not regarded as statistically significant and is therefore not considered as a predictor of employee satisfaction. Therefore, employee satisfaction is influenced by internal marketing through internal product, collaborative culture, organisational structure, internal people and internal process. A significantly positive relationship thus exists between these internal marketing mix elements and employee satisfaction. This is confirmed by ELSamen and Alshurideh (2012) stating that a healthy working environment is conducive in securing employee satisfaction and stimulating employee ability to deliver enhanced service performance (for example a clean working environment).

\section{Section 2}

\section{H8: There is a significantly positive relationship between GradDP employee satisfaction and affective commitment}

The results from the regression indicates a positive relationship between employee satisfaction and affective commitment and therefore support the hypothesis $(\beta=0.835$, $p<0.05)$. The direction of the relationship was congruent with a priori theorising since a strong positive relationship was found between employee satisfaction and affective commitment. The null hypothesis can therefore be rejected in favour of the alternative hypothesis. The adjusted $\mathrm{R}^{2}$-value of 0.693 indicates that approximately $69.3 \%$ of the variance in affective commitment is predicted by employee satisfaction. A significantly positive relationship between employee satisfaction and affective commitment proves to exist, indicating that $\mathrm{H} 8$ can be accepted. Bailey, Albassami and Al-Meshal (2016) concur with the finding stating that a well developed and managed internal marketing strategy has a positive influence on the attitudes of employees, resulting in increased job satisfaction and employee commitment.

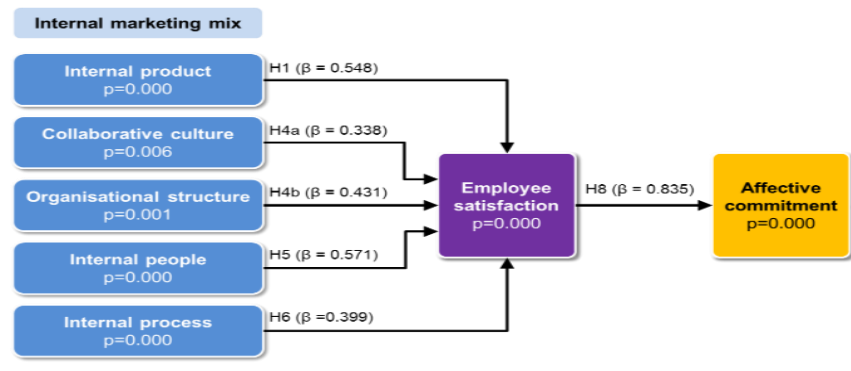
Figure 2: The final refined theoretical model proposed
based on the overall regression results.

From Figure 2 it becomes evident that GradDP employee satisfaction is influenced by internal marketing through internal product, collaborative culture, organisational structure, internal people and internal process. Therefore, a significantly positive relationship between these internal marketing mix elements and GradDP employee satisfaction were established. In addition to this, a significantly positive relationship between GradDP employee satisfaction and affective commitment also emerged from the data.

\section{Discussion}

The contribution of the study is both theoretical and practical. From a theoretical perspective, the results validated that the scales used to measure the internal marketing, customer satisfaction and affective commitment constructs are reliable and valid. The proposed model in the study has been confirmed, endorsing the relationships between the different internal marketing elements, GradDP employee satisfaction and affective commitment within the South African banking environment.

From a managerial perspective, the study makes a contribution by assisting the South African banking industry in understanding how internal marketing, as a strategy, can nurture GradDP employee satisfaction, thereby leading to the positive affective commitment of GradDP employees. This outcome will, however, be dependent on whether GradDP employees perceive the internal marketing mix elements as positive. Hume and Hume (2015) note the importance of internal marketing as a change management strategy to engage all internal stakeholders in business strategy development. They argue that internal marketing should be applied as a comprehensive system aimed at incorporating the employees and internal divisions of an organisation in support of the overall strategy of the business. Considering this, it therefore becomes increasingly important for organisations to develop an innovative approach in terms of their internal marketing strategy development that is built around mutual value creation, education, development, training, empowerment and continuous engagement to ensure greater GradDP employee satisfaction, and therefore employee commitment. Therefore, an internal stakeholder analysis will assist the bank in identifying and emphasising the most appropriate internal marketing mix elements that can assist in enhancing GradDP employee satisfaction, which can ultimately result in stronger affective commitment amongst this category of employees.

From a theoretical perspective, the contribution of the study was twofold. In the first instance, the study established that there are selected internal marketing elements that have a direct, positive influence on GradDP employee satisfaction, and that the satisfaction experiences of these employees are positively linked to their affective commitment within the South African retail banking industry. In addition, it can also be argued that only selected internal marketing constructs (internal product, collaborative culture, organisational structure, internal people and internal process) that are claimed in theory to have an influence on employee satisfaction do indeed have an influence on the satisfaction levels of GradDP employees, and therefore an influence on their affective commitment. It is furthermore also important to take cognisance of the fact that internal marketing within the South African retail banking environment remains an unexplored area of research, and limited studies have focused specifically on the influence of internal marketing as a 
strategy on GradDP employee satisfaction and ultimately their affective commitment. The importance of this study is further emphasised by the fact that it informs the South African banking industry on the different elements to be considered when formulating an internal marketing strategy for GradDP employees with the intention of strengthening their satisfaction levels, and ultimately their affective commitment. The internal marketing mix elements could in future be used by researchers to investigate the influence of internal marketing on different domains, such as employee retention, service quality or brand association. It is in this light that the study makes a definite contribution to the internal marketing literature through the proposition of useful and relevant measurement dimensions.

In the second instance, the study provides an enhanced understanding of the influence of internal marketing constructs on GradDP employee satisfaction and affective commitment, from the perspective of a competitive industry such as the retail banking industry within South Africa. The research study recommends a model that explains how the different internal marketing constructs directly influence GradDP employee satisfaction, with the latter influencing affective commitment. Therefore the positive influence of internal marketing elements such as internal product, collaborative culture, organisational structure, internal people and internal process on the satisfaction of GradDP employees and their affective commitment can empower South African banks with the ability to enhance their employee satisfaction levels, thereby strengthening GradDP employee commitment and their eventual retention. Through this approach, South African retail banks can strengthen their internal stakeholder focus, thereby increasing their ability to enhance external service delivery as a competitive advantage (Kanyurhi \& Akonkwa, 2016).

\section{Managerial implications}

The empirical results obtained in the step-wise regression clearly identified internal people and internal product to be the two most significant variables determining GradDP employee satisfaction. For this reason, only these two elements are discussed in this section and guidelines related to each of these elements are provided.

\section{Internal product}

In order to attract the right kind of employees into the retail banking sector of South Africa, the internal product needs to be reviewed and the following elements, namely career advancement opportunities, training and development, empowerment and role fit and clarity, ought to be included as part of the internal product offering. In this study these components proved to potentially contribute positively to assist GradDPs to engage and connect with the organisations that employ them. When these employees feel connected to the organisation and cared for, they experience high levels of satisfaction and loyalty, leading to higher levels of retention. The following guidelines are thus provided:
- Guideline 1: It is important to note that not all employees feel comfortable in a collaborative environment or in autonomous positions. For this reason, retail banks in South Africa need to ensure that the job fit between the employee and the role they are recruited for is accurate.

Saeed and Asghar (2012) support this view, stating that it is essential to ensure that there is a good fit between the job of the employee and the role he/she is expected to play. Matanda and Ndubisi (2013) concur, stating that there needs to be a sufficient level of comfort between the employees, their roles and the internal environment. If employees adapt well to an organisation, they are less likely to leave. Retail banks must thus also ensure congruence between the employees' values and career goals on the one hand and the culture of the organisation on the other to secure the satisfaction of employees, their productivity and long-term retention. Roos (2005) supports this view and states that employees' feelings and attitudes towards their job (such as satisfaction) are influenced by the way in which they perceive the organisational culture. Employee-centred organisational culture is characterised by higher levels of employee support and collaboration, and are associated with meeting employee needs and therefore higher levels of employee satisfaction (also see Ajang, 2013; George, Owoyemi \& Onakala, 2012; Beer, 2012; Newsham et al., 2009). Finally, it is important that the right employees are recruited into the organisation. GradDP employees should be carefully screened through competency assessments. Other employees in the employing department could participate in the interview process to ensure that the right kind of person is brought into the organisation to ensure a good fit with the existing team.

- Guideline 2: Employees need to know exactly what it is they are expected to do and deliver on. Employees should understand the bank's external marketing strategy and what role they play in delivering on promises made to both internal and external customers. Melcrum Connecting Communications (2013) support this view by stating that in the case where employees has a clear understanding of both the internal and external marketing strategy of the organisation, they are in a stronger position to have clarity on their function in delivering the strategy and the rationale behind management decisions. For this reason, GradDP employees need clear job descriptions that specify the functional responsibilities of the job, the competencies required for the job and what a graduate is further expected to do, including being part of an innovation committee of a community of practice. The job description needs to be linked to the employees' key performance indicators and it is essential that regular feedback is provided regarding their performance and the meeting of these objectives. This approach would, in turn, facilitate open communication between managers and subordinates. This finding supports King's (2010) assertion that the right employees should be recruited into the organisation and provided with clear job descriptions and key performance indicators which clearly specify performance deliverables. Further to this, employees should understand how their individual performance criteria tie into the broader organisational objectives. Employees 
should also be aware of how their deliverables contribute to the bank's overall performance as such awareness can enhance satisfaction levels. Satisfied employees tend to feel more passionate about their jobs and as a result put more effort into serving internal and external customers. Ibhar Technologies (2011) also indicated that since satisfied employees make satisfied customers, the satisfaction and retention of talented employees create a stable and experienced labour force that delivers higher service quality to customers at a lower cost, leading to improved customer satisfaction, retention and profitability

\section{Internal people}

The construct 'internal people' is recognised as having the strongest influence on employee satisfaction. Therefore, retail banks in South Africa need to ensure that the components of internal people, namely leadership style, relationship with supervisors/direct managers and relationship with co-workers, are firmly entrenched within the bank in a way that creates employee satisfaction and stronger levels of affective commitment. In particular, it is necessary to ensure that open channels of communication are established between management and subordinates through the consideration of the guidelines discussed below.

- Guideline 3: Create opportunities whereby GradDP employees can work together as a team to solve problems and develop. These employees (GradDPs) are most satisfied when working in areas characterised by high levels of collaboration and empowerment. To provide service excellence to internal customers, strong internal relationships are required. For this reason, the relationship with co-workers is paramount for organisational success. This view supports the argument put forward by Lenke et al. (2010) who indicate that when employees feel comfortable at work and feel that the people they work with care for them, the emotions they express are positive, leading to a positive impact on the internal environment and the way in which they serve both internal and external customers. For this reason it is important that co-workers treat each other with respect. Co-workers are regarded as the employees' 'work family', so when employees identify with, share the same values, and can relate to their co-workers, they are more inclined to bond as a team, which heightens feelings of satisfaction. GradDP employees, often seen as part of the so-called Generation Y group, have high levels of social consciousness and look to peers for mutual support. This group of employees would prefer to work collaboratively with others than operate in isolation (also see Shaw, Bailey \& Williams, 2011; Shaw \& Fairhurst, 2008).

- Guideline 4: Retail banks need to create an environment that supports and encourages social interactions amongst employees in order to develop trust and deeper relationships. For this reason, social activities and team-building interventions are a necessity for this group in order to strengthen their social bonds. Higher levels of social capital result in more informed and engaged employees, which results in higher levels of satisfaction and loyalty towards the organisation (also see Ali, 2012: 245; Ali \& Haider, 2010: 40).

\section{Limitations of the study}

The main limitation of this study is that it was only conducted among GradDP employees. Findings could have been significantly different had the study been conducted among other populations within the retail banking community, such as middle and senior level management. Multiple regression was not possible for this study and as a result the researchers could not establish through multivariate analysis which internal marketing element was the strongest predictor of employee satisfaction.

\section{Conclusion}

This article discussed the internal marketing mix influence on the satisfaction of GradDP employees to improve their level of satisfaction at South African retail banks with graduate development programmes. It was also investigated whether employee satisfaction do have a relationship with affective commitment. The theoretical discussion provided in this article has emphasised that internal marketing is not being used as a strategy to enhance the inclusive satisfaction and retention of employees. For this reason, retail banks in South Africa must consider the importance of a comprehensive internal marketing programme which is integrated into the bank's overall marketing strategy. Such an approach will ensure that retail banks hire and train employees to deliver on the promises made through the external marketing strategy. Through aligning processes and employees with the external marketing strategy and external customer needs, retail banks are able to create a strategic advantage that is difficult to replicate, ensuring a sustainable competitive advantage. With the aid of internal marketing, retail banks are able to enhance GradDP employee satisfaction, which results in higher levels of affective commitment and GradDP employees remaining with the organisation for longer, thereby contributing to better service, stronger financial performance and profitability.

\section{References}

ABSA (Amalgamated Banks of Southern Africa). 2011. Graduate programme. [Online] available: http://www.absa.co.za/absacoza/ content.jsp?/Home/Personal/Our-Customers/Students/GraduateProgramme.

Aburoub, A.S., Hersh, A.M. \& Aladwan, K. 2011. 'Relationship between internal marketing and service quality with customer's satisfaction', International Journal of Marketing Studies, 3(2): 10718.

Abzari, M. \& Ghujali, T. 2011) 'Examining the impact of internal marketing on organisational citizenship behaviour', International Journal of Marketing Studies, 3(4): 95-104.

Ahmad, M.B., Wasay, E. \& Malik, S.U. 2012. 'Impact of employee motivation on customer satisfaction: Study of airline industry in Pakistan', Interdisciplinary Journal of Contemporary Research in Business, 4(6): 531-39. 
Ajang, P.E. 2013. Assessing the role of work motivation on employee performance. [Online] available: http://www.divaportal.org/smash/ get/diva2:140549/FULLTEXT01.

Akroush, M.N., Abu-ElSamen, A.A., Samawi, G.A. \& Odetallah, A.L. 2013. 'Internal marketing and service quality in restaurants', Marketing Intelligence \& Planning, 3(4): 304-36.

Ali, A. \& Haider, J. 2012. 'Impact of internal organisational communications on employee job satisfaction: Case of some Pakistani Banks', Global Advanced Research Journal of Management and Business Studies, 1: 38-44.

Ali, N. 2012. 'An exploratory study into the implementation of internal marketing in small insurance brokers in the United Kingdom', Journal of Financial Services Marketing, 17: 242-54.

Appelbaum, S.H., Louis, D., Makarenko, D., Saluja, J., Meleshko, O. \& Kulbashian, S. 2013. 'Participation in decision making: A case study of job satisfaction and commitment (part one)', Industrial and Commercial Training, 45(4): 222-29.

Atan, J.B., Raghavan, S., Hasnaa, N. \& Mahmood, N. 2015. 'Impact of Training on Employees' Job Performance: A Case Study of Malaysian Small Medium Enterprise', Review of Management, 5(1/2):40-50.

Awwad, M.S. \& Agti, D.A.M. 2011. 'The impact of internal marketing on commercial banks' market orientation', International Journal of Bank Marketing, 29(4): 308-332.

Bailey, A.A, Albassami, F. \& Al-Meshal, S. 2016. 'The roles of employee job satisfaction and organizational commitment in the internal marketing-employee bank identification relationship', International Journal of Bank Marketing, 34(6):821-840.

Baldauf, A., Cravens, K.S., Diamantopoulos, A. \& Zeugner-Roth, K.P. 2009. 'The impact of product-country image and marketing efforts on retailer-perceived brand equity: An empirical analysis', Journal of Retailing, 85(4): 437-52.

Banking Association of South Africa. 2013. The South African banking sector overview for 2012. [Online] available: http://www.banking.org.za/index.php/our-industry/2012-southafrican-banking-sector-overview/.

Beer, M. 2012. Organisational behaviour and development. [Online] available: http://www.hbs.edu/research/facpubs/ workingpapers/papers2/9798/98-115.pdf.

Bojei, J. \& Abu, M.L. 2014. 'The underlying dimensions of relationship marketing in the Malaysian mobile service sector', Journal of Relationship Marketing, 13(3): 169-190.

Boles, J., Madupalli, R., Rutherford, B. \& Wood, J.A. 2007. 'The relationship of facets of salesperson job satisfaction with affective organisational commitment', Journal of Business \& Industrial Marketing, 22(5): 311-21.

Burin, C. 201. The perceived influence of the elements of internal marketing on the brand image of staffing agencies in South Africa. Master's dissertation, Department of Business Management, University of Johannesburg.

Burin, C., Roberts-Lombard, M. \& Klopper, H.B. 2015. 'The perceived influence of the elements of internal marketing on the brand image of a staffing agency group', South African Journal of Business Management, 46(1): 71-82.

Calisir, F., Gumussoy, C.A. \& Iskin, I. 2011. 'Factors affecting intention to quit among IT professionals in Turkey', Personnel Review, 40(4): 514-33.

Chen, C.J. \& Huang, J.W. 2007. 'How organisational climate and structure affect knowledge management: The social interaction perspective', International Journal of Information Management, 27: 104-18.

CIA (Central Intelligence Agency). 2012. The world factbook. [Online] available: https://www.cia.gov/library/publications/theworld-factbook/geos/sf.html.

Conduit, J., Matanda, M.J. \& Mavondo, F.T. 2014. 'Balancing the act: The implications of jointly pursuing internal customer orientation and external customer orientation'. Journal of Marketing Management, 30(13-14):1320-1352.

Culiberg, B. \& Rojsek, I. 2010. 'Identifying service quality dimensions as antecedents to customer satisfaction in retail banking', Economic and Business Review, 12(3): 151-66.

Dimitriades, Z.S. \& Papalexandris, N. 2011. 'Test of a service profit chain model in the Greek banking sector', EuroMed Journal of Business, 6(2): 142-54

ELSamen, A.A. \& Alshurideh, M. 2012. 'The impact of internal marketing on internal service quality: A case study in a Jordanian pharmaceutical company', International Journal of Business and Management, 7(19): 84-95.

Fang, S-R, Chang, E., Ou, C-C \& Chou, C-H. 2014. 'Internal market orientation, market capabilities and learning orientation', European Journal of Marketing, 48(1/2):170-192.

Ferdous, A.S., Herington, C. \& Merrilees, B. 2013. 'Developing an integrative model of internal and external marketing', Journal of Strategic Marketing, 21:7.

FNB (First National Bank). 2011. Graduate programme. [Online] available: https://www.fnb.co.za/careers/graduates/main/fnbgraduate-development-programme.html.

Gebre, B., Hallman, P., Minukas, M. \& O’Brien, B. 2012. Transforming government performance through lean management. McKinsey Center for Government, McKinsey \& Company.

George, O.J., Owoyemi, O. \& Onakala, U. 2012. 'Theorising the concept of organisational artefacts: How it enhances the development of corporate/organisational identity', International Journal of Business Administration, 3(4): 37-44.

Gibbs, T. \& Ashill, N.J. 2013. 'The effects of high performance work practices on job outcomes: Evidence from frontline employees in Russia', International Journal of Bank Marketing, 31(4): 305-26.

Global Entrepreneurship Monitor. 2011. The UCT Centre for Innovation and Entrepreneurship. [Online] available: http://www.gemconsortium.org/docs/download/2313.

Global Services Forum. 2013. Global importance of services. [Online] available: http://unctad.org/en/conferences/gsf/2013/ pages/importance-of-services.aspx. 
Grayson, D. \& Sanchez-Hernandez, I.M. 2010. Using internal marketing to engage employees in corporate responsibility. Cranfield University Working Paper Series.

Gummesson, E. 2014. 'Productivity, quality and relationship marketing in service operations: A revisit in a new service paradigm', International Journal of Contemporary Hospitality Management, 26(5): 656 - 662

Gummesson, E., Lusch, R.F. \& Vargo, S.L. 2010. 'Transitioning from service management to service-dominant logic: Observations and recommendations', International Journal of Quality and Service Sciences, 2(1): 8-22.

Guzman, M., Rodriguez, B. \& Manautou, P. 2013. The link between customer satisfaction and employee satisfaction in the restaurant industry: An analysis of full service restaurants in Tampico, Mexico. [Online] available: http://www.tam.itesm.mx/documentos/ANEXO $\% 20004 \% 20 J U A N \% 20 D I . p d f$.

Hair, J.F., Wolfinbarger, M.F., Ortinau, D.J. \& Bush, R.P. 2010. Essentials of marketing research. $2^{\text {nd }}$ Edition. New York: McGrawHill.

Halepota, J.A. \& Shah, N. 2011. 'An empirical investigation of organisational antecedents on employee job satisfaction in a developing country', Transforming Government: People, Process and Policy, 5(3): 280-94.

Helm, S.V., Renk, U. \& Mishra, A. 2015. 'Exploring the impact of employees' self-concept, brand identification and brand pride on brand citizenship behaviors', European Journal of Marketing, 50(1/2): 58-77.

Holder, M. \& Berndt, A. 2011. 'The effect of changes in servicescape and service quality perceptions in a maternity unit', International Journal of Health Care Quality Assurance, 24(5): 389405 .

Huang, P. 2010. Exploring the relationship between work-life and stress. Center for WorkLife Law Issue Brief, UC Hastings College of the Law, San Francisco.

Huang, M. \& Chen, M-Y. 2013. 'Internal marketing, customer orientation, and organizational commitment: Moderating effects of work status', Psychological Reports: Employment Psychology \& Marketing, 113(1):180-198.

Huang, Y-T. \& Rundle-Thiele, S. 2015. 'A holistic management tool for measuring internal marketing activities', Journal of Services Marketing, 29(6/7): 571-584.

Hume, C. \& Hume, M. 2015. 'The critical role of internal marketing in knowledge management in not-for-profit organizations', Journal of Nonprofit \& Public Sector Marketing, 27:1, 23-47.

Ibhar Technologies 2011. Employee satisfaction lead to better customer management. Ibhar Business Partner Program. [Online] available: http://www.scribd.com/doc/86641065/Retention.

Ieong, C.Y. \& Lam, D. 2016. 'Role of internal marketing on employees' perceived job performance in an Asian integrated resort', Journal of Hospitality Marketing \& Management, 25(5): 589-612.

Illiopoulos, E. \& Priporas, C.V. 2011. 'The effect of internal marketing on job satisfaction in health services: A pilot study in public hospitals in Northern Greece', BMC Health Services Research, October(9): 1-8.

Imran, H., Arif, I., Cheema, S. \& Azeem, M. 2014. 'Relationship between job satisfaction, job performance, attitude towards work, and organizational commitment', Entrepreneurship and Innovation Management Journal, 2(2): 135-144.

IndexMundi. 2015. South Africa GDP - composition by sector. [Online] available: http://www.indexmundi.com/south_africa/gdp_ composition_by_sector.html.

Javadein, S.S.R., Rayej, H., Estiri, M. \& Ghorbani, H. 2010. 'The role of internal marketing in creation of a sustainable competitive advantages', Trends in Applied Science Research, 6(4): 364-74.

Joung, H-W., Goh, B.K., Huffman, L., Yuan, J.J. and Surles, J. 2015. 'Investigating relationships between internal marketing practices and employee organizational commitment in the foodservice industry', International Journal of Contemporary Hospitality Management, 27(7):1618-1640.

Kaurav, R.P.S., Prakash, M., Chowdhary, N. \& Briggs, A.D. 2016. 'Internal marketing: review for next generation businesses', Journal of Services Research, 16(1):81-95.

Kameswari, A.V. \& Rajyalakshmi, N. 2012. Role of internal marketing in job satisfaction of employees in State Bank of India. Paper presented at the $12^{\text {th }}$ AIMS International Conference on Management, Pune, India, January 1-4.

Kanyurhi, E.B., Akonkwa, D.B.M. 2016. 'Internal marketing, employee job satisfaction, and perceived organizational performance in microfinance institutions', International Journal of Bank Marketing, 34(5):773-796.

Karatepe, O.M. 2011. 'Do job resources moderate the effect of emotional dissonance on burnout? A study in the city of Ankara, Turkey', International Journal of Contemporary Hospitality Management, 23(1): 44-65.

Kaur, J. \& Sharma, S.K. 2015. 'Internal marketing: Scale development and validation', Vision, 19(3): 236-247.

Kent, R. 2007. Marketing research: Approaches, methods and applications in Europe. [Online] available: https://www.cengagebrain.com.au/content/kent03279_1844803279 _02.01_chapter01.pdf.

Kim, M., Knutson, B.J. \& Han, J. 2015. 'Understanding employee delight and voice from the internal marketing perspective', Journal of Hospitality Marketing \& Management, 24:260-286.

King, C. 2010. Building and measuring employee based brand equity. [Online] available: http://www98.griffith.edu.au/ dspace/bitstream/handle/10072/33650/64027_1.pdf?sequence=1.

Kotler, P., Armstrong, G., Tait, M., Beneke, J., Bhowan, K., Blake, S., Botha, E., Cassim, S., De Jager, J., Frey, N., George, R., Golestaneh, M., Human, D., Rammile, N., Roberts-Lombard, M., Rootman, C., Rugimbana, R., Van Zyl, J., Vigar-Ellis, D. \& Wait, M. 2010. Principles of marketing. Cape Town: Pearson Education. Lee, S.Y. 2006. 'Expectations of employees toward the workplace and environmental satisfactions', Facilities, 24(9/10): 343-53.

Lenke, U., Suar, D. \& Mohapatra, P.K.J. 2010. 'Customer satisfaction in Indian commercial banks through total quality 
management approach', Total Quality Management, 21(12): 131541.

Leonard, D. \& Murphy, W. 2013. A wake-up call: Achieving customer satisfaction through your employees. [Online] available: http://williamhmurphy.com/wp-content/themes/WillMurphy/files/ publications/a_wakeup_call.pdf.

Lioukas, C.S. \& Reuer, J.J. 2015. 'Isolating trust outcomes from exchange relationships: Social exchange and learning benefits of prior ties in alliances', Academy of Management Journal, 58(6): $1826-1847$

Lumley, E.J., Coetzee, M., Tladinyane, R. \& Ferreira, N. 2011. 'Exploring the job satisfaction and organisational commitment of employees in the information technology environment', Southern African Business Review, 15(1): 100-18.

Mac, L. \& Shirley, H.K. 2015. 'The impact of internal marketing on organizational commitment: the mediating roles of customer orientation and internal communication', Euro Asia Journal of Management, 25(1/2): 3-13.

Malmström, M.M. \& Johansson, J. 2016. 'Social exchange in collaborative innovation: Maker or breaker', Journal of Innovation and Entrepreneurship, 5(4): 1-20.

Matanda, M.J. \& Ndubisi, N.O. 2013. 'Internal marketing, internal branding, and organisational outcomes: The moderating role of perceived goal congruence', Journal of Marketing Management, 29(9/10): 1030-55.

McDermott, E., Mangan, J. \& O'Connor, M. 2006. 'Graduate development programmes and satisfaction levels', Journal of European Industrial Training, 30(6): 456-71.

Melcrum Connecting Communications. 2013. Creating a coherent strategic narrative. [Online] available: https://www.melcrum.com/ research/strengthen-leader-communication/creating-coherentstrategic-narrative.

Mishra, S. 2010. 'Internal marketing: A tool to harness employees' power in service organisations in India', International Journal of Business and Management, 5(1): 185-90.

Mishra, T. \& Sinha, S. 2014. 'Employee motivation as a tool to implement internal marketing', International Journal of Commerce, Business and Management, 3(5): 672-680.

Morgan, R.M. \& Hunt, S.D. 1994. 'The commitment-trust theory of relationship marketing', Journal of Marketing, 58, 20-38.

Narteh, B. \& Odoom, R. 2015. 'Does internal marketing influence employee loyalty? Evidence from the Ghanaian banking industry', Services Marketing Quarterly, 36(2): 112-135

National Treasury. 2011. National Treasury policy document. [Online] available: http://www.treasury.gov.za/documents/national $\% 20$ budget $/ 2011 /$ A\%20safer\%20financial\%20sector\%20to\%20ser ve\%20South\%20Africa\%20better.pdf.

Ndubisi, N.O. \& Ndubisi, G.C. 2013. 'Sustainable internal marketing and internal customer motivation model: An African small- and medium-sized enterprise perspective', Journal of Asian and African Studies, 48(4): 521-538.
Newsham, G.R., Brand, J., Donnelly, C.L., Veitch, J.A., Aries, M. \& Charles, K.E. 2009. Linking indoor environment conditions to job satisfaction: A field study. [Online] available: http://www.nrccnrc.gc.ca/obj/irc/doc/pubs/nrcc49714/nrcc49714.pdf.

Ng, E., Fang, W-T and Lien, C-Y. 2016. 'An empirical investigation of the impact of commitment and trust on internal marketing', Journal of Relationship Marketing, 15(1-2): 35-53.

Ozuem, W., Limb, N. \& Lancaster, G. 2016. 'Exploring the locus of internal marketing', Journal of Strategic Marketing, 1-17.

Peltier, J.W., Pointer, L. \& Schibrowsky, J.A. 2008. 'Nurse loyalty and the relational marketing continuum', Health Marketing Quarterly, 23(4): 109-29.

Peters, S.C. \& Mazdarani, E. 2008. The impact of employee empowerment on service quality and customer satisfaction in service organisations. Bachelor thesis, University of Mälardalen, Sweden.

Roos, W. 2005. The relationship between employee motivation, job satisfaction and corporate culture. Master's thesis, University of South Africa.

Ruizalbaa, J.L., Bermúdez-Gonzáleza, G., Rodríguez-Molinab, M.A. \& Blancaaa, M.J. 2014. 'Internal market orientation: An empirical research in hotel sector', International Journal of Hospitality Management, 38:11-19.

Saeed, M.M. \& Asghar, M.A. 2012. 'Examining the relationship between training, motivation and employees job performance: The moderating role of person job fit', Journal of Basic and Applied Scientific Research, 2(12): 12177-83.

Sahi, G.K., Lonial, S., Gupta, M. \& Seli, N. 2013. 'Revisiting internal market orientation: A note', Journal of Services Marketing, 27(5): 385-403.

Shaw, G., Bailey, A. \& Williams, A.M. 2011. 'Service dominant logic and its implications for tourism management: The coproduction of innovation in the hotel industry', Tourism Management, 32(2): 207-14.

Shaw, S. \& Fairhurst, D. 2008. 'Engaging in a new generation of graduates', Education and Training, 50(5): 366-78.

Sharma, P., Kong, T.T.C. \& Kingshott, R.P.J. 2016. 'Internal service quality as a driver of employee satisfaction, commitment and performance: Exploring the focal role of employee well-being', Journal of Service Management, 27(5): 773-797.

Suh, T. \& Lee, J. 2016. 'Internal audience segmentation and diversity in internal communication', Corporate Communications: An International Journal, 21(4):450-464.

Tanskanen, K. 2015. 'Who wins in a complex buyer-supplier relationship? A social exchange theory based dyadic study', International Journal of Operations \& Production Management, 35(4): 577-603.

Turkyilmaz, A., Akman, G., Ozkan, C. \& Pastuszak, Z. 2011. 'Empirical study of public sector employee loyalty and satisfaction', Industrial Management \& Data Systems, 111(5): 675-96.

Uzzi, J. 2010. Work design and Six Sigma: Improve jobs and processes. [Online] available: http://www.isixsigma.com/ 
index.php?option=com_k2\&view=item\&id=968: work-design-andsix-sigma-improve-jobs-and-processes $\&$ Itemid $=182 \& \mathrm{tmpl}=$ component\&print $=1 . h t m l$.

Yang, J.T. 2012. The development and emergence of the internal marketing concept. [Online] available: http://www.hicbusiness.org/ biz2003proceedings/Jen-Te\%20Yang.pdf.

Yang, Y., Lee, P.K.C. \& Cheng, T.C.E. 2016. 'Continuous improvement competence, employee creativity, and new service development performance: A frontline employee perspective', International Journal of Production Economics, 171: 275-288.

Yang, F-H, Huang, C-H \& Wei, C-Y. 2015. 'The relationship between internal marketing, employee well-being, and customer service quality - the service industry in Taiwan', The International Journal of Organizational Innovation, 8(2): 40-57.

Zaman, K., Javaid, N., Arshad, A. \& Bibi, S. 2012. 'Impact of internal marketing on market orientation and business performance', International Journal of Business and Social Science, 3(12): 76-87.

Zeithaml, V.A., Bitner, M.J. \& Gremler, D.D. 2012. Services marketing: Integrating customer focus across the firm. $2^{\text {nd }}$ Edition. New York: McGraw-Hill. 